\title{
Eosinophil Lysophospholipase
}

National Cancer Institute

\section{Source}

National Cancer Institute. Eosinophil Lysophospholipase. NCI Thesaurus. Code C100091.

Eosinophil lysophospholipase (142 aa, $\sim 16 \mathrm{kDa}$ ) is encoded by the human CLC gene. This protein is involved in phospholipid metabolism. 